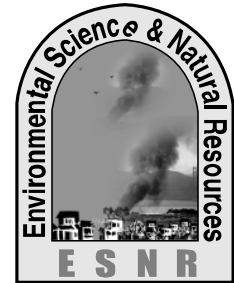

J. Environ. Sci. \& Natural Resources, 5(2): 167 - 172, 2012

ISSN 1999-7361

\title{
Effect of Shoot Bending and Fruit Thinning on Productivity of Guava
}

\author{
A. A. Mamum, M. H. Rahman and M. A. Rahim
}

Department of Horticulture, Bangladesh Agricultural University, Mymensingh-2202

\begin{abstract}
The study was carried out at the Germplasm Centre of Fruit Tree Improvement Programme (GPC-FTIP), Bangladesh Agricultural University, Mymensingh during the period February, 2011 to March, 2012 to find out the effect of shoot bending and fruit thinning on productivity of guava. The treatments of the experiment were four varieties of guava viz., Swarupkathi, BAU piyara-5, Chiang Mai (round) and Chiang Mai (long) and six different management practices viz., (i) control (no shoot bending + no fruit thinning); (ii) shoot bending; (iii) 25\% fruit thinning; (iv) 50\% fruit thinning; (v) $75 \%$ fruit thinning and (vi) $100 \%$ fruit thinning. The ages of the plants were $4-5$ years. Results revealed that the variety Chiang Mai (round) showed superiority over BAU piyara-5, Chiang Mai (long) and Swarupkathi in respect of fruit yield (15.63 kg/plant) and fruit retention (72.92\%) during on-season but during off-season, Swarupkathi showed superiority over Chiang Mai (round), BAU piyara-5 and Chiang Mai (long) in case of number of flowers set per plant (127.44), number of fruits set per plant (75.28), fruit retention $(88.66 \%)$ and yield $(11.78 \mathrm{~kg} / \mathrm{plant})$. Different management practices had significant effect on all studied parameters in both seasons. Fifty percent fruit thinning treatment showed the highest fruit yield $(20.46 \mathrm{~kg} / \mathrm{plant})$ and $75 \%$ fruit thinning treatment performed lowest fruit yield $(10.06 \mathrm{~kg} / \mathrm{plant})$ during on-season but during off-season shoot bending performed highest fruit yield $(13.50 \mathrm{~kg} / \mathrm{plant})$. Highest fruit retention in both seasons (on-season $89.28 \%$ and off-season 90.47\%) was observed in 50\% fruit thinning treatment. In case of combined effect of variety and different management practices, $50 \%$ fruit thinning treatment combined with Chiang Mai (round) produced highest yield (23.15 kg/plant) and fruit retention $(92.72 \%)$ during on-season, but shoot bending treatment combined with Swarupkathi gave the highest yield (16.06 $\mathrm{kg} / \mathrm{plant}$ ) and 50\% fruit thinning combined with Swarupkathi showed highest fruit retention (94.12\%) during off-season.
\end{abstract}

Key words: Guava, Shoot bending, Fruit thinning, Productivity

\section{Introduction}

Guava, a berry like fruit of various myrtaceous trees or shrubs of the genus Psidium, especially Psidium guajava of botanical family Myrtaceae. It was originated in tropical America (Mexico to Peru) but at present the major guava producing countries are the USA, Cuba, Taiwan, Mexico, Peru, China, Malaysia, India, Pakistan, Thailand and Bangladesh. Guava is often called the "apple of the tropics". It claims to be the most important fruit in respect of area and production after mango, banana, jackfruit, pineapple, and melon in Bangladesh (BBS, 2010). It grows everywhere in Bangladesh in the homestead gardens even without or little care but commercially cultivated in Barisal, Sylhet, Gazipur, Pirojpur, Swarupkathi, Jessore, Rajshahi and Chittagong (Mondal, 2000). Guavas are up to 5 times richer in vitamin $\mathrm{C}$ than oranges. It is also rich in pectin, which has industrial use for jelly production (Bose and Mitra, 1990). It contains appreciable amount of vitamin A, calcium, phosphorus, potassium, sulphur, sodium, chlorine, iron, magnesium, pantothenic acid, riboflavin, thiamin and niacin (FAO, 2009). The leaves of the plant have medicinal values, which aid in curing diarrhoea, swelling and bleeding of gums (Goncalves et al., 2008). Most of the people of Bangladesh suffer from malnutrition specially vitamins and minerals. Guava is a good and cheap source of readily uptake able vitamins and minerals. Guava plant is quite hardy, prolific bearer and highly remunerative even without much care (Bose and Mitra, 1990).

In Bangladesh, some of the varieties of guava set fruits twice in a year. Once in March to April and another in November to December. In the later one production is low but quality of fruits is better. Normally higher yield of guava is found that ripens during rainy season which are insipid, watery, poor in taste with poor keeping quality and low market prices. In order to have a winter harvest, fruit thinning is advisable. According to Sing et al. (1996), flower thinning from guava plants during summer, improved fruit quality and increase yield during next winter. Shoot bending is one of the ways to produce better quality fruits in the offseason (Sarker et al., 2005). In case of bending of branch wood tension of branch is increased and phloem formation decreased. As a result photosynthetic product pass slowly from the shoots of bent branch as to the other parts, maintaining increased $\mathrm{C}: \mathrm{N}$ ratio and induce more flowering and fruit set. Bending forced dormant reproductive buds into growth. The upright branch produces fewer flowers and fruits than the bent branch (Ito et al., 1999). Considering the above facts an experiment was carried out to study the effect of bending and fruit thinning for off-season production of guava.

\section{Materials and Methods}

Experimental site: The experiment was carried out at the Germplasm Centre of the Fruit Tree 
Improvement Programme (FTIP), Department of Horticulture, Bangladesh Agricultural University, Mymensingh during the period from February, 2011 to March, 2012.

Two separate methods were followed:

Shoot bending: The branches which were healthy and disease free lateral shoots were selected for shoot bending with care. Shoot bending was done in such a way that the bent branch did not broken down after bending. Shoots were bent at its antigrowth (at $90^{\circ}$ angle) with the help of a piece of rope. Before shoot bending 3-5 leaves were kept at the upper portion of the branch to continue its photosynthesis and respiration process and rest leaves were removed off.

Fruit thinning: Total number of fruits per plant in each replication was counted after fruit set. Out of these according to treatment fruits were thinned randomly by hand when the average weight of individual fruit was 15-20 g.

According to the management practices, the experiment consists of two factors with three replications. These are following- Factor $\mathbf{A}$ : It consists of four varieties; i) $\mathrm{V}_{1}=$ Swarupkathi, ii) $\mathrm{V}_{2}=$ BAU piyara -5 , iii) $\mathrm{V}_{3}=$ Chiang Mai (round) and $\mathrm{V}_{4}=$ Chiang Mai (long). Factor B: six management practices; $\mathrm{M}_{1}$ : Control (no shoot bending and no fruit thinning), $\mathrm{M}_{2}$ : Shoot bending, $M_{3}: 25 \%$ fruit thinning, $M_{4}: 50 \%$ fruit thinning, $M_{5}$ : $75 \%$ fruit thinning and $\mathrm{M}_{6}: 100 \%$ fruit thinning.

Statistical analysis: The collected data on different parameters were statistically analyzed. The analyses of variances of the parameters under study were performed following F-variance test. The significance of the differences of treatment means were evaluated by least significant difference(LSD) test at $5 \%$ and $1 \%$ levels of probability (Gomez and Gomez, 1984).

\section{Results and Discussion}

\section{Number of flowers set per plant}

Performance of variety: Significant variations were observed on the number of flowers set per plant both in on-season and off-season. The highest number of flowers set per plant was observed in Swarupkathi in both seasons (on-season 422.22 and off-season 127.44) and the lowest was observed in Chiang Mai (long) (Table 1).

Effect of management practices: The effect of different management practices on the number of flowers set per plant in guava was significant in both seasons. The highest number of flowers set per plant was recorded in the shoot bending treatment during on-season (312.33) and off-season it was
(111.33). The lowest (214.83) was recorded in the $75 \%$ fruit thinning treatment during on-season and during off-season it was (41.75 in the $100 \%$ fruit thinning treatment (Table 2). Ghose (2003) reported that bending of shoots increases number of flowers per plant during off-season that also supports the present experimental results.

Combined effect of variety and management practices: The combined effect of variety and different management practices on the number of flowers set per plant was significant in both seasons. The highest number of flowers set per plant was recorded in the treatment combination of Swarupkathi with shoot bending treatment in both seasons (on-season 543.33) and off-season 173.00) and the lowest number of flower set per plant was recorded in the treatment combination of Chiang Mai (long) with the control treatment in both seasons (Table 3).

\section{Number of fruits set per plant}

Performance of variety: The variety had significant effect on the number of fruits set per plant both in on-season and off-season. The highest number of fruits set per plant was recorded in the variety Swarupkathi in both seasons (on-season 311.44 and off-season 75.28). The lowest number of fruits set per plant was recorded in the variety Chiang Mai (long) both in on-season (126.39) and off-season (27.28) respectively (Table 1$)$.

Effect of management practices: The number of fruits set per plant has been presented in table 2, which was found to be significantly affected by different management practices in both seasons. The shoot bending treatment resulted the highest number of fruits set per plant both on and off season (246.86) and (67.33) respectively). Shoot bending increased the fruits set per plant during offseason in also reported by Sarker and Ghose (2006) that supports the present experimental results.

Combined effect of variety and management practices: The combined effect of variety and different management practices on the number of fruits set per plant was significant in both seasons. The highest number of fruits set per plant was recorded in the treatment combination of Swarupkathi with shoot bending treatment in both seasons (on-season 413.33 and off-season 117.33). The lowest number of fruits set per plant (79.67) was recorded in the treatment combination of Chiang Mai (long) with $25 \%$ fruit thinning treatments during on-season and during off-season it was (13.33) in the treatment combination of Chiang Mai (long) with $100 \%$ fruit thinning treatments (Table 3). 
Table 1. Effect of variety on number of flowers set per plant and number of fruits set per plant in guava

\begin{tabular}{|l|c|c|c|c|}
\hline \multirow{2}{*}{ Variety } & \multicolumn{2}{|c|}{ Number of flowers set per plant } & \multicolumn{2}{c|}{ Number of fruits set per plant } \\
\cline { 2 - 5 } & On-Season & Off-season & On-season & Off-season \\
\hline Swarupkathi & 422.22 & 127.44 & 311.44 & 75.28 \\
\hline BAU piyara-5 & 230.78 & 69.11 & 183.72 & 59.06 \\
\hline Chiang Mai (round) & 212.28 & 47.94 & 127.22 & 29.78 \\
\hline Chiang Mai (long) & 210.61 & 45.5 & 126.39 & 27.28 \\
\hline LSD (0.05) & 0.13 & 0.24 & 10 & 13.41 \\
\hline LSD (0.01) & 0.17 & 0.32 & 13.34 & 17.89 \\
\hline Level of significance & $* *$ & $* *$ & $* *$ & $* *$ \\
\hline
\end{tabular}

Table 2. Effect of different management practices on number of flowers set per plant and number of fruits set per plant in guava

\begin{tabular}{|l|c|c|c|c|}
\hline \multirow{2}{*}{ Management practices } & \multicolumn{2}{|c|}{ Number of flowers set per plant } & \multicolumn{2}{c|}{ Number of fruits set per plant } \\
\cline { 2 - 5 } & On-Season & Off-season & On-season & Off-season \\
\hline Control & 249.67 & 84.58 & 130 & 59.25 \\
\hline Shoot bending & 312.33 & 111.33 & 246.86 & 67.33 \\
\hline $25 \%$ fruit thinning & 280.83 & 78 & 186.92 & 53.33 \\
\hline $50 \%$ fruit thinning & 288.33 & 72.25 & 211.83 & 48.5 \\
\hline $75 \%$ fruit thinning & 214.83 & 42.08 & 183.5 & 30.33 \\
\hline $100 \%$ fruit thinning & 227.83 & 41.75 & 164.08 & 28.33 \\
\hline LSD (0.05) & 0.16 & 0.3 & 12.24 & 16.42 \\
\hline LSD (0.01) & 0.21 & 0.4 & 16.34 & 21.92 \\
\hline Level of significance & $* *$ & $* *$ & $* *$ & $* *$ \\
\hline
\end{tabular}

Table 3. Combined effect of variety and different management practices on number of flowers set per plant and number of fruits set per plant in guava

\begin{tabular}{|c|c|c|c|c|c|}
\hline \multirow{2}{*}{ Variety } & \multirow[t]{2}{*}{ Management practices } & \multicolumn{2}{|c|}{ Number of flowers set/plant } & \multicolumn{2}{|c|}{ Number of fruits set /plant } \\
\hline & & On-Season & Off-season & On-season & Off-season \\
\hline \multirow{6}{*}{ Swarupkathi } & Control & 343.33 & 139 & 237.67 & 78 \\
\hline & Shoot bending & 543.33 & 173 & 413.33 & 117.33 \\
\hline & $25 \%$ fruit thinning & 408.67 & 143.33 & 287.67 & 81.33 \\
\hline & $50 \%$ fruit thinning & 489.33 & 137 & 367.67 & 82.67 \\
\hline & $75 \%$ fruit thinning & 425.67 & 87.33 & 326.67 & 45 \\
\hline & $100 \%$ fruit thinning & 323 & 85 & 235.67 & 47.33 \\
\hline \multirow{6}{*}{$\begin{array}{c}\text { BAU } \\
\text { piyara-5 }\end{array}$} & Control & 219.33 & 92.67 & $169 . .67$ & 60.67 \\
\hline & Shoot bending & 323 & 121 & 239 & 92.67 \\
\hline & $25 \%$ fruit thinning & 192.67 & 71 & 160.33 & 65 \\
\hline & $50 \%$ fruit thinning & 280.33 & 54 & 202 & 43 \\
\hline & $75 \%$ fruit thinning & 202 & 38.67 & 159.67 & 32.67 \\
\hline & $100 \%$ fruit thinning & 190.67 & 37.33 & 148.67 & 34.33 \\
\hline \multirow{6}{*}{ Chiang Mai (round) } & Control & 184.33 & 49.33 & 89 & 30.67 \\
\hline & Shoot bending & 323 & 72.67 & 110.33 & 41.67 \\
\hline & $25 \%$ fruit thinning & 180.33 & 47 & 96.33 & 31 \\
\hline & $50 \%$ fruit thinning & 242.33 & 46 & 132 & 27 \\
\hline & $75 \%$ fruit thinning & 182 & 31 & 100 & 18 \\
\hline & $100 \%$ fruit thinning & 189 & 27 & 235.67 & 15.33 \\
\hline \multirow{6}{*}{ Chiang Mai (long) } & Control & 175.67 & 57.33 & 95.67 & 35.67 \\
\hline & Shoot bending & 206.33 & 78.67 & 130.67 & 49.67 \\
\hline & $25 \%$ fruit thinning & 161.67 & 50.67 & 79.67 & 30 \\
\hline & $50 \%$ fruit thinning & 201 & 52 & 111.33 & 30.33 \\
\hline & $75 \%$ fruit thinning & 127.67 & 31.33 & 105.33 & 19.67 \\
\hline & $100 \%$ fruit thinning & 178.67 & 17.67 & 135.67 & 13.33 \\
\hline \multicolumn{2}{|l|}{ LSD (0.05) } & 0.32 & 0.59 & 24.49 & 32.84 \\
\hline \multicolumn{2}{|l|}{$\operatorname{LSD}(0.01)$} & 0.42 & 0.79 & 32.69 & 43.83 \\
\hline \multicolumn{2}{|l|}{ Level of significance } & $* *$ & $* *$ & $* *$ & $* *$ \\
\hline
\end{tabular}




\section{Percent fruit drop}

Performance of variety: The variety had significant effect on percent fruit drop both in onseason and off-season. The highest percentage of fruit drop was recorded in the variety Chiang Mai (long) in both seasons (on-season $34.74 \%$ and offseason $17.65 \%)$. The lowest percent of fruit drop was noticed in the variety Chiang Mai (round) (27.08) during on-season and during off-season (11.34) in the variety Swarupkathi (Table 4).

Effect of management practices: Percent fruit drop has been found to be significantly affected by different management practices both in on-season and off-season. The highest percentage of fruit drop (31.87) was recorded in the control treatment and the lowest percentage of fruit drop (10.72) was recorded in 50\% fruit thinning treatment during onseason (Table 5). During off-season, the highest percentage of fruit drop (25.26) was recorded in the control treatment and the lowest percentage of fruit drop (9.53) was recorded in 50\% fruit thinning treatment during off-season (Table 5). Tahir and Hamid (2002) reported that flower and fruit drop was less in fruit thinning plant which also supports the present experimental results.

Combined effect of variety and management practices: There was a significant difference in percentage of fruit drop due to combined effect of variety and different management practices in both seasons. The highest percentage of fruit drop (32.77) was recorded in the treatment combination of Chiang Mai (long) with control treatment during on-season and during off-season it was (28.48) recorded in the treatment combination of Chiang Mai (round) with control treatment (Table 6).

\section{Percent fruit retention}

Performance of variety: The variety had significant effect on percent fruit retention in both seasons. The highest percentage of fruit retention (72.92) was found in the variety Chiang Mai (round) and the lowest (65.26\%) was found in variety Chiang Mai (long) during on-season. During off-season, the highest percentage of fruit retention (88.66) was found in the variety Swarupkathi and the lowest percentage of fruit retention (82.35) was found in the variety Chiang Mai (long) (Table 4).

Effect of management practices: Percent fruit retention has been found to be significantly affected by different management practices in both seasons. The highest percentage of fruit retention was recorded in 50\% fruit thinning treatment in both seasons (on-season $89.28 \%$ and off-season $90.47 \%$ ). The lowest percentage of fruit retention was recorded in control treatment in both seasons (Table 5). Sharifuzzaman (1996) found maximum percentage of fruit retention in 50\% fruit thinning that supports the present experimental results.

Combined effect of variety and management practices: The combined effect of variety and different management practices was also significant in both seasons. The highest percentage of fruit retention (92.72) was recorded in the treatment combination of Chiang Mai (round) with 50\% fruit thinning treatment and the lowest percentage of fruit retention (68.32) was recorded in the treatment combination of Swarupkathi with control treatment during on-season (Table 6). During offseason, the highest percentage of fruit retention (94.12) was recorded in the treatment combination of Swarupkathi with 50\% fruit thinning treatment and the lowest percentage of fruit retention (71.62) was recorded in the treatment combination of Chiang Mai (long) with control treatment (Table $6)$.

\section{Yield ( $\mathrm{kg} /$ plant)}

Performance of variety: Variety had significant effect on fruit yield ( $\mathrm{kg} / \mathrm{plant})$. The highest fruit yield $(15.63 \mathrm{~kg} / \mathrm{plant})$ was recorded in Chiang Mai (round) and the lowest fruit yield (11.82 kg/plant) was recorded in Swarupkathi during on-season (Table 4). During off-season, the highest fruit yield $(11.78 \mathrm{~kg} / \mathrm{plant})$ was recorded in Swarupkathi and the lowest fruit yield $(8.78 \mathrm{~kg} / \mathrm{plant})$ was recorded in Chiang Mai (long) (Table 4).

Effect of management practices: A significant variation was observed in case of fruit yield $(\mathrm{kg} / \mathrm{plant})$ due to different management practices in both seasons. The highest fruit yield (20.46 $\mathrm{kg} / \mathrm{plant}$ ) was recorded in 50\% fruit thinning treatment and the lowest fruit yield $(10.06 \mathrm{~kg} / \mathrm{plant})$ was observed in $75 \%$ fruit thinning treatment during on-season (Table 5). During off-season, the highest fruit yield $(13.50 \mathrm{~kg} / \mathrm{plant})$ was recorded in shoot bending treatment and the lowest fruit yield (7.19 kg/plant) was recorded in 100\% fruit thinning treatment (Table 5). Shoot bending increased the fruit yield per plant and quality fruit during offseason (Sarker et al., 2005). Fruit thinning to the extent of $50 \%$ increased the fruit yield per plant and fruit yield reduced in $75 \%$ or more percent of fruit thinning (kabir, 2005) that's supports the present experimental results.

Combined effects of variety and management practices: The combined effect of variety and different management practices on fruit yield (kg/plant) was significant both in on-season and offseason. The highest fruit yield $(23.15 \mathrm{~kg} / \mathrm{plant})$ was recorded in the treatment combination of Chiang Mai (round) with $50 \%$ fruit thinning during on-season during off-season it was (16.06 kg/plant) in the treatment combination of Swarupkathi with shoot bending treatment (Table 6). 
Table 4. Effect of variety on percent fruit drop, percent fruit retention and yield in guava

\begin{tabular}{|l|c|c|c|c|c|c|}
\hline \multirow{2}{*}{ Variety } & \multicolumn{2}{|c|}{ Percent fruit drop (\%) } & \multicolumn{2}{c|}{ Percent fruit retention (\%) } & \multicolumn{2}{c|}{ Yield (kg/plant) } \\
\cline { 2 - 7 } & On-season & Off-Season & On-season & Off-season & On-season & Off-season \\
\hline Swarupkathi & 29.43 & 11.34 & 70.57 & 88.66 & 11.82 & 11.78 \\
\hline BAU piyara-5 & 32.58 & 15.72 & 67.42 & 84.28 & 14.4 & 9.67 \\
\hline Chiang Mai (round) & 27.08 & 17.48 & 72.92 & 82.52 & 15.63 & 8.95 \\
\hline Chiang Mai (long) & 34.74 & 17.65 & 65.26 & 82.35 & 13.98 & 8.78 \\
\hline LSD (0.05) & 0.08 & 0.15 & 0.02 & 0.05 & 48.69 & 24.31 \\
\hline LSD (0.01) & 0.11 & 0.2 & 0.03 & 0.06 & 64.99 & 32.45 \\
\hline Level of significance & $* *$ & $* *$ & $* *$ & $* *$ & $* *$ & $* *$ \\
\hline
\end{tabular}

Table 5. Effect of different management on percent fruit drop, percent fruit retention and yield in guava

\begin{tabular}{|c|c|c|c|c|c|c|}
\hline \multirow{2}{*}{$\begin{array}{l}\text { Management } \\
\text { practices }\end{array}$} & \multicolumn{2}{|c|}{ Percent fruit drop $(\%)$} & \multicolumn{2}{|c|}{ Percent fruit retention $(\%)$} & \multicolumn{2}{|c|}{ Yield (kg/plant) } \\
\hline & On-season & Off-Season & On-season & Off-season & On-season & Off-season \\
\hline Control & 31.87 & 25.26 & 68.13 & 74.83 & 13.67 & 8.43 \\
\hline Shoot bending & 29.33 & 24.42 & 70.75 & 76 & 16.66 & 13.5 \\
\hline $25 \%$ fruit thinning & 16.61 & 14.5 & 83.39 & 85.5 & 16.9 & 10.16 \\
\hline $50 \%$ fruit thinning & 10.72 & 9.53 & 89.28 & 90.47 & 20.46 & 12.43 \\
\hline $75 \%$ fruit thinning & 11.55 & 9.96 & 88.45 & 90.04 & 10.06 & 8.09 \\
\hline $100 \%$ fruit thinning & 0 & 9.63 & 0 & 90.37 & 0 & 7.19 \\
\hline LSD (0.05) & 0.1 & 0.19 & 0.03 & 0.06 & 59.63 & 29.77 \\
\hline $\operatorname{LSD}(0.01)$ & 0.13 & 0.25 & 0.03 & 0.08 & 79.6 & 39.74 \\
\hline Level of significance & $* *$ & $* *$ & $* *$ & $* *$ & $* *$ & $* *$ \\
\hline
\end{tabular}

Table 6. Combined effect of variety and different management practices on percent fruit drop, percent fruit retention and yield in guava

\begin{tabular}{|c|c|c|c|c|c|c|c|}
\hline \multirow{2}{*}{ Variety } & \multirow{2}{*}{$\begin{array}{c}\text { Management } \\
\text { practices }\end{array}$} & \multicolumn{2}{|c|}{ Percent fruit drop (\%) } & \multicolumn{2}{|c|}{ Percent fruit retention (\%) } & \multicolumn{2}{|c|}{ Yield (kg/plant) } \\
\hline & & On-season & Off-season & On-season & Off-season & On-season & Off-season \\
\hline \multirow{6}{*}{ Swarupkathi } & Control & 31.68 & 17.37 & 68.32 & 82.63 & 12.7 & 10.42 \\
\hline & Shoot bending & 28.48 & 19.47 & 69.62 & 80.53 & 16.42 & 16.06 \\
\hline & $25 \%$ fruit thinning & 14.25 & 10.32 & 85.75 & 89.68 & 15.95 & 12.72 \\
\hline & $50 \%$ fruit thinning & 11.33 & 5.88 & 88.63 & 94.12 & 18.41 & 14.46 \\
\hline & $75 \%$ fruit thinning & 14.65 & 8.62 & 85.35 & 92.6 & 7.45 & 8.54 \\
\hline & $100 \%$ fruit thinning & 0 & 6.4 & 0 & 93.6 & 0 & 8.5 \\
\hline \multirow{6}{*}{$\begin{array}{l}\text { BAU } \\
\text { piyara-5 }\end{array}$} & Control & 32.13 & 25.28 & 68.87 & 74.52 & 14.47 & 8.76 \\
\hline & Shoot bending & 29.42 & 25.08 & 70.58 & 74.52 & 18.23 & 13.59 \\
\hline & $25 \%$ fruit thinning & 17.55 & 15.32 & 82.45 & 84.68 & 17.17 & 9.64 \\
\hline & $50 \%$ fruit thinning & 8.54 & 7.28 & 91.46 & 93.72 & 21.07 & 11.56 \\
\hline & $75 \%$ fruit thinning & 14.4 & 10.1 & 85.6 & 89.9 & 11.29 & 7.24 \\
\hline & $100 \%$ fruit thinning & 0 & 11.06 & 0 & 88.94 & 0 & 7.25 \\
\hline \multirow{6}{*}{$\begin{array}{l}\text { Chiang Mai } \\
\text { (round) }\end{array}$} & Control & 30.66 & 26.73 & 69.72 & 73.27 & 14.27 & 7.22 \\
\hline & Shoot bending & 28.48 & 27.97 & 71.62 & 72.03 & 16.43 & 10.15 \\
\hline & $25 \%$ fruit thinning & 20.4 & 18.12 & 79.6 & 81.88 & 17.07 & 9.19 \\
\hline & $50 \%$ fruit thinning & 7.28 & 10.22 & 92.72 & 89.78 & 23.15 & 12.33 \\
\hline & $75 \%$ fruit thinning & 14.4 & 12.6 & 85.6 & 87.4 & 10.86 & 8.17 \\
\hline & $100 \%$ fruit thinning & 0 & 10.28 & 0 & 89.72 & 0 & 6.63 \\
\hline \multirow{6}{*}{$\begin{array}{l}\text { Chiang Mai } \\
\text { (long) }\end{array}$} & Control & 32.77 & 28.48 & 69.33 & 71.62 & 13.24 & 7.31 \\
\hline & Shoot bending & 29.91 & 28.11 & 70.09 & 71.89 & 15.54 & 10.19 \\
\hline & $25 \%$ fruit thinning & 14.25 & 14.25 & 85.75 & 85.75 & 17.42 & 9.1 \\
\hline & $50 \%$ fruit thinning & 10.54 & 8.54 & 89.46 & 91.35 & 19.22 & 11.35 \\
\hline & $75 \%$ fruit thinning & 14.65 & 14.65 & 85.35 & 85.35 & 10.63 & 8.41 \\
\hline & $100 \%$ fruit thinning & 0 & 10.85 & 0 & 89.15 & 0 & 6.35 \\
\hline \multicolumn{2}{|l|}{ LSD (0.05) } & 0.19 & 0.37 & 0.05 & 0.12 & 119.26 & 59.54 \\
\hline \multicolumn{2}{|c|}{ LSD (0.01) } & 0.26 & 0.5 & 0.07 & 0.16 & 159.2 & 79.49 \\
\hline \multicolumn{2}{|c|}{ Level of significance } & $* *$ & $* *$ & $* *$ & $* *$ & $* *$ & $* *$ \\
\hline
\end{tabular}




\section{References}

BBS. 2010. Year Book of Agricultural Statistics of Bangladesh. Bangladesh Bureau of Statistics. Statistics Division. Ministry of Planning. Govt. of the People's Republic of Bangladesh.

Bose, T. K. and Mitra, S. K. 1990. Guava. In: Fruits Tropical and Subtropical. Ed. T. K. Bose, Nayaprakash, India. pp. 280-303.

FAO. 2009. United Nations Development Programme. Soil Survey Project of Bangladesh. Soil Res. Tech. Rep. 3:101-159.

Ghosh, B. 2003. Progress report of NATP on "Offseason flower of guava". Faculty of Horticulture, BCKV, Mohonpur, Nadia, West Bengal. pp3-5.

Gomez, R. A. and Gomez, A. A. 1984. Statistical Procedure for Agricultural Research $\left(2^{\text {nd }}\right.$ edn.). International Rice Research Institute. A Willey Interscience Pub. pp. 28-192.

Goncalves, F. A.; Neto, M. A.; Bezerra, J. N. S.; Macrae, A.; Sousa, O. V.; Fonteles-filho, A. A. and Regine, H. S. F. 2008. Antibacterial activity of guava, Psidium guajava linnaeus, leaf extracts on diarrhea-causing enteric bacteria isolated from seabob shrimp, xiphopenaeus kroyeri (Heller). Rev. Inst. Med. trops. S. Paulo., 50(1): 11-15.

Ito, A.; Yaegaki, H.; Hayama, H.; Kusaba, S.; Yamaguchi, I. and Yoshioka, H. 1999. Bending shoots stimulates flowering and influences hormone levels in lateral buds of Japanese pear. Hort. Sci., 34, 1224-1228.
Kabir, L. 2005. Growth and yield and quality of guava as influenced by management practices. Ph.D Thesis. Department of Horticulture. BAU, Mymensingh. pp. 61-64.

Mondal, M. F. 2000. Production and storage of fruits (in Bangla). Mrs. Afia Mondal, BAU Campus, Mymensingh-2202, p. 311.

Singh, A. K.; Gorakh, S.; Pandey, D.; Rajan S. and Singh, G. 1996. Effect of cropping pattern on quality attributes of guava (Psidium guajava) fruits. Indian J. Agric. Sci., 66 (6): 348-352.

Sarkar, A.; Ghosh, B.; Kundu, S. and Sukul, P. 2005. Effect of shoot pruning and bending on yield and fruit quality in guava cv. L-49. Environ. Ecol., 23(3): 621-623.

Sarker, A. and Ghosh, B. 2006. Studies on growth, yield and economics in guava cv. L-9 by shoot pruning and bending. J. Interacdemicia. 10(3): 327-330.

Sharifuzzaman, S. 1996. Effect of fruit thinning and growth regulators on the yield and quality of guava cv. Kazipiara. M. S. Thesis, Department of Horticulture, BAU, Mymensingh. p. 73.

Tahir, F. M. and Hamid, K. 2002. Studies of physicochemical changes due to fruit thinning in Guava (Psidium guajava L.). J. Biol. Sci., 2: 744-745. 